Supporting Information

\title{
Computational Prediction of Superlubric Layered Heterojunctions
}

Enlai Gao", Bozhao Wü, Yelingyi Wang, Xiangzheng Jia, Wengen Ouyang, and Ze Liu*

Department of Engineering Mechanics, School of Civil Engineering, Wuhan University, Wuhan, Hubei 430072, China.

${ }^{\#}$ These authors contribute equally.

*Corresponding author. Email: ze.liu@whu.edu.cn. 


\section{This Supporting Information contains following sections:}

$\underline{1, \text { Molecular dynamics simulation protocol }}$

$\underline{2, \text { Rules of constructing heterojunction and different } \mathrm{vdW} \text { dispersion corrections for the }}$ calculations of interlayer binding energy

$\underline{\text { 3, Effects of high binding energy on the lattice deformation of heterojunction }}$

$\underline{4, \text { Effects of interlayer distances on the sliding PES and shear stress }}$

$\underline{5, \text { Heterojunction configurations used in the friction tests and the calculations of surface }}$ $\underline{\text { smoothness }}$

$\underline{6, \text { Influences of the relative orientation and sliding direction on the friction }}$ 


\section{1, Molecular dynamics simulation protocol}

Molecular dynamics (MD) simulations using large-scale atomic/molecular massively parallel simulator (LAMMPS) computational package ${ }^{1}$ were carried out to reveal the effect of binding energy on the interfacial friction of heterojunction. In all simulations, the aligned heterojunction graphene/hexagonal boron nitride $\left(\mathrm{C}_{2} / h\right.$-BN, $\left.\theta=0^{\circ}\right)$ with the size of $L \approx 136 \AA$ that is approximate to the size of Moire pattern was used. Herein, we adopt the proposed simulation set-up by Song et al. ${ }^{2}$ : The sliding graphene was dragged over the flat and rigid $h$ $\mathrm{BN}$ by a rigid duplicate of the sliding graphene layer that moves at a constant velocity of 10 $\mathrm{m} / \mathrm{s}$ (Figure S1a); A classical harmonic spring was used to build connection between the atom of the sliding layer and the image atom of the duplicate layer. The in-plane interactions of the sliding graphene layer were described by using the reactive bond order (REBO) potential. ${ }^{3}$ The interactions between the sliding and duplicate graphene layers were described by classical harmonic springs with the spring constant $\left(K_{\|}\right)$of $11 \mathrm{meV} / \AA^{2}$ in the lateral $(x, y)$ directions for

all carbon atoms. ${ }^{2,4}$ The interlayer interactions between the sliding graphene and the rigid $h$ BN substrate were described by the Lennard-Jones (L-J) potential, which is determined by the following form:

$$
V_{i j}=4 \varepsilon\left[\left(\frac{\sigma}{r_{i j}}\right)^{12}-\left(\frac{\sigma}{r_{i j}}\right)^{6}\right]
$$

where $\varepsilon$ represents the potential well and $\sigma$ represents the distance between carbon and nitrogen/boron atoms. In this work, the adopted L-J parameters $(\sigma, \varepsilon)$ were taken from Ref. ${ }^{5}$ as listed in Table S1. In all simulations, periodic boundary conditions (PBC) in lateral directions were employed. The Newton equations of motion were integrated using the Verlet algorithm with a time step of $1 \mathrm{fs}$. For each simulation, a full structural relaxation of the sliding monolayer using the FIRE algorithm ${ }^{6}$ was first performed with a force criteria of $10^{-6} \mathrm{eV} / \AA$. Afterwards, sliding simulations were performed by moving the rigid duplicate at a constant velocity $V$ of 10 $\mathrm{m} / \mathrm{s}$ along the zigzag $(x)$ direction of the substrate. All simulations were performed at finite temperature $(0.1 \mathrm{~K})$ under the NVT ensemble with a time constant of 1 fs. The total simulation time is $2 \mathrm{~ns}$. The average friction stress was calculated by time averaging the shear stress at 
steady-state sliding (1.2-2.0 ns, Figure S1b). The instantaneous shear stress was calculated as $F_{K} / A_{\text {area, }}$ where $F_{K}$ is the lateral force of the duplicated graphene along the sliding direction, and $A_{\text {area }}$ is the basal area of the sliding system. The amplitude of the interaction potential $\left(U_{\text {corr }}\right)$ was defined as the difference of the maximum and minimum energy potential in the time range of 1.2-2.0 ns. To obtain the reliable results, each simulation was performed 6 times with different random numbers for the generating an ensemble of velocity at the specified temperature $(0.1 \mathrm{~K})$. The statistical errors can be calculated using 6 independent simulations. The effects of thermal fluctuations on the simulation results for the aligned graphene $/ h$-BN heterojunction $\left(\theta=0^{\circ}\right)$ have been investigated by Song et al., ${ }^{2}$ which indicate that the influence of thermal fluctuation (at temperatures up to $300 \mathrm{~K}$ ) on the friction is quite small.
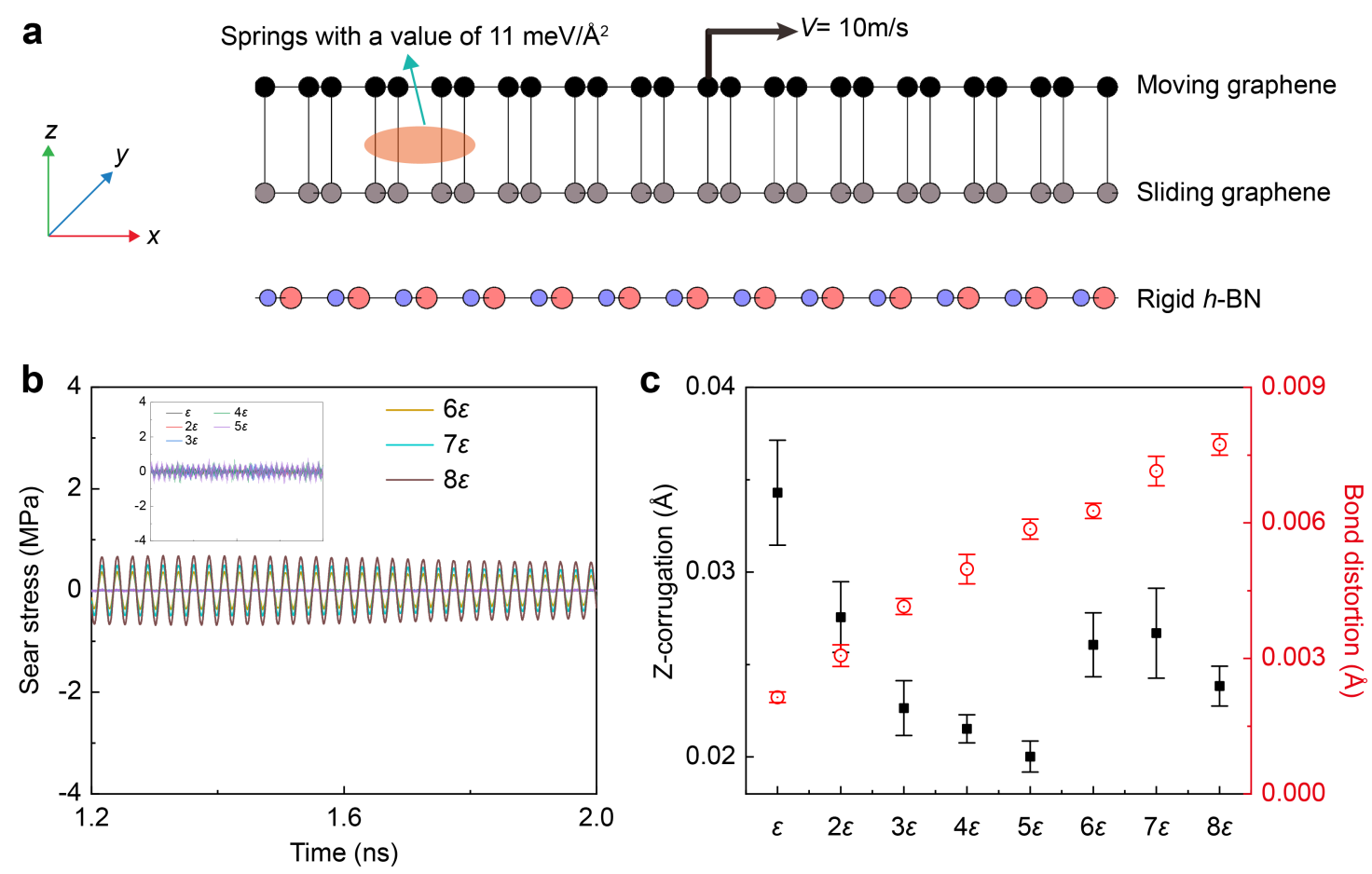

Figure S1. (a) Illustration of the simulation set-up. The sliding graphene layer moving over a rigid $h$-BN substrate is realized by dragging a rigid duplicate of the sliding graphene that moves at a constant velocity $V$. Each atom of the sliding graphene is connected to its image within the rigid duplicate via harmonic springs. With different interlayer interactions between the sliding graphene and rigid $h$-BN substrate, panel (b) shows the stimulated instantaneous shear stress at steady-state sliding (1.2-2.0 ns). All the results presented here were obtained using uniform 
duplicate/graphene spring constants of $K_{\|}=11 \mathrm{meV} / \AA^{2}$ and a driving velocity of $10 \mathrm{~m} / \mathrm{s}$. (c) The out-of-plane $\left[\Delta z=\max \left(z_{i}\right)-\min \left(z_{i}\right)\right]$ and local bond distortions $\left[\Delta L_{\text {bond }}=\max \left(L_{\mathrm{bond}, i}\right)-\right.$ $\left.\min \left(L_{\mathrm{bond}, i}\right)\right]$ of the sliding graphene layer as a function of interlayer interactions were evaluated.

Table S1. Original and modified parameters of the L-J parameter $(\sigma, \varepsilon)$ for the interlayer interactions between carbon, boron/nitrogen atoms. ${ }^{5}$

\begin{tabular}{lll}
\hline & Carbon-Boron & Carbon-Nitrogen \\
\hline$\sigma(\AA)$ & 3.41 & 3.37 \\
$\varepsilon(\mathrm{meV})$ & 3.29 & 4.07 \\
$2 \varepsilon(\mathrm{meV})$ & 6.59 & 8.14 \\
$3 \varepsilon(\mathrm{meV})$ & 9.88 & 12.20 \\
$4 \varepsilon(\mathrm{meV})$ & 13.17 & 16.27 \\
$5 \varepsilon(\mathrm{meV})$ & 16.47 & 20.34 \\
$6 \varepsilon(\mathrm{meV})$ & 19.76 & 24.41 \\
$7 \varepsilon(\mathrm{meV})$ & 23.05 & 28.48 \\
$8 \varepsilon(\mathrm{meV})$ & 26.34 & 32.54 \\
\hline
\end{tabular}




\section{2, Rules of constructing heterojunction and different vdW dispersion corrections for the calculations of interlayer binding energy}

As shown in the insets of Figure S2a, the co-incidence site lattice $\operatorname{method}^{7}$ was used to construct the heterojunction. On the basis of two rules: (i) Minimizing the number of atoms in the unit cell of heterojunctions; (ii) Minimizing the mean misfit strain $\left(\varepsilon_{\mathrm{m}}\right)$ between two materials in a constructed heterojunction, in this work, $\varepsilon_{\mathrm{m}}$ is set to be less than $1 \%{ }^{8}{ }^{8}$ Here, $\varepsilon_{\mathrm{m}}$ is calculated as $\varepsilon_{\mathrm{m}}=\left(\left|\varepsilon_{11}\right|+\left|\varepsilon_{22}\right|+\left|\varepsilon_{12}\right|\right) / 3$, where $\varepsilon_{11}$ and $\varepsilon_{22}$ are the in-plane normal strain along the base vectors of $a$ and $b$, respectively, and $\varepsilon_{12}$ is the in-plane shear strain of 2D cells. According to Figure S2a, The two rules balance the rationality of heterojunctions structures and the computational cost, e.g., the red point with $\varepsilon_{\mathrm{m}}$ of $0.89 \%$ and total atoms of 26 was used to determine the $h-\mathrm{BN} / 2 \mathrm{H}-\mathrm{MoS}_{2}$ heterojunction with the relative orientation at twist angle $(\Delta \varphi)$ of $19.11^{\circ}$.

To verify the reliability of the used vdW dispersion correction (DFT-D3) ${ }^{10}$ for the calculations of the binding energy, other common vdW correction approaches of optB86b$\mathrm{vdW},{ }^{11} \mathrm{vdW}-\mathrm{DF} 2^{12}$ and DFT-dDsC ${ }^{13}$ were also used for test, which agree with the DFT-D3 method (Figure S2b). 

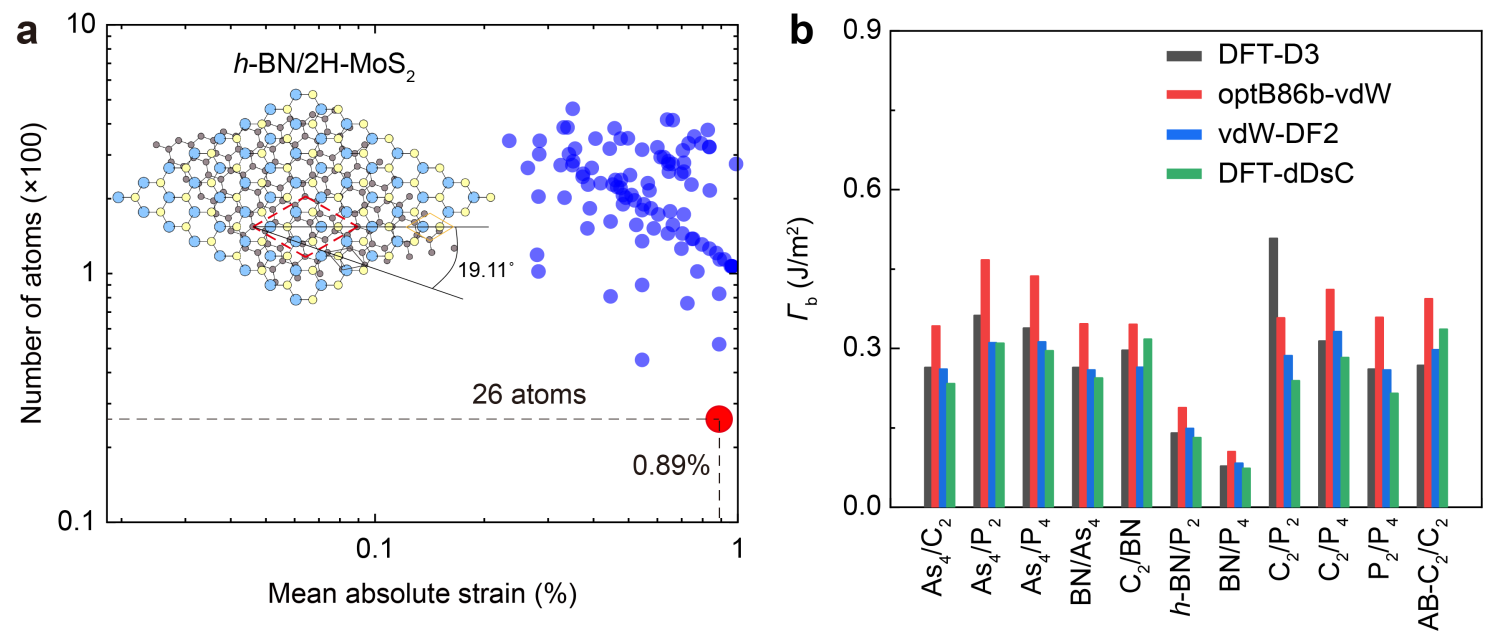

Figure S2. (a) Illustration of constructing heterojunctions using the co-incidence site lattice method, ${ }^{7}$ e.g., $h-\mathrm{BN} / 2 \mathrm{H}-\mathrm{MoS}_{2}$ with the relative orientation at twist angle $(\Delta \varphi)$ of $19.11^{\circ}$. The marked red circle was determined by minimizing the number of atoms and mean misfit strain $\left(\varepsilon_{\mathrm{m}}<1 \%\right)$, which balance the rationality of heterojunctions structures and the computational cost. (b) Binding energies of typical heterojunctions by using different vdW correction methods. 


\section{3, Effects of high binding energy on the lattice deformation of heterojunction}

As discussed in main text, there are 17 heterojunctions with high binding energy $\left(\Gamma_{\mathrm{b}}>1\right.$ $\mathrm{J} / \mathrm{m}^{2}$ ). The high binding energy leads to a large vibration of atoms in the contact surfaces during sliding, which would result in local commensurate contact (a pinned state) and hence increasing the friction. For example, the $\mathrm{Si}_{2} / \mathrm{B}_{5}\left(1.04 \mathrm{~J} / \mathrm{m}^{2}\right)$ and $\mathrm{C}_{2} / \mathrm{Sc}_{3} \mathrm{C}_{2}\left(1.29 \mathrm{~J} / \mathrm{m}^{2}\right)$ heterojuntions, their relaxed atomic configurations are shown in Figure S3. Compared with the initial configuratios, the high interlayer interactions cause a significant interatomic deformation and reduce the interlayer distances, which leads to the breaking of smooth surface.

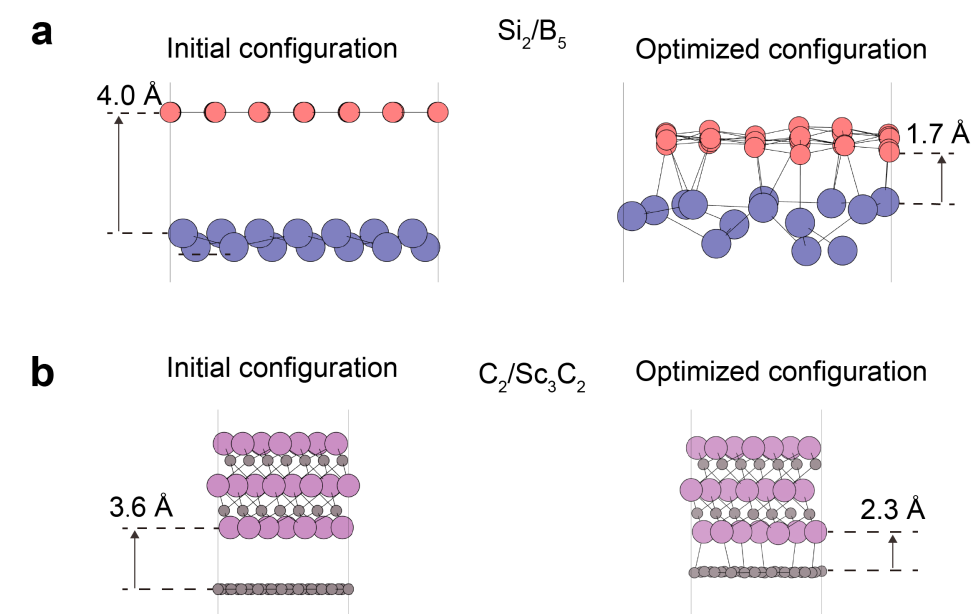

Figure S3. Side views of heterojunction configurations before (left) and after (right) structural optimization for the (a) $\mathrm{Si}_{2} \mathrm{~B}_{5}$ and (b) $\mathrm{C}_{2} / \mathrm{Sc}_{3} \mathrm{C}_{2}$ heterojunctions. The calculated binding energies were larger than $1 \mathrm{~J} / \mathrm{m}^{2}$, causing significant interatomic deformations and the reduced interlayer distances, and some chemical bonds have formed at the interfaces. 


\section{4, Effects of interlayer distances on the sliding PES and shear stress}

To validate our first-principles calculation protocol,we perform benchmark tests for the bilayer graphene (AB stacking mode) configuration, as shown in the main test (Figure 5a and Figure S4a) with equlilibrium interlayer distance $(d)$ of $3.52 \AA$ on the basis of the DFT-D3 method. The obtained sliding potential energy surface (PES) is smaller than the previous work using the DFT-D method with the $d$ of 3.25 3.31 $\AA$, ${ }^{14,15}$ but close to the results using vdW-DF method with the $d$ of $3.62 \AA .{ }^{15}$ This difference is attributed to the different equilibrium interlayer distance $(d)$ using different methods. ${ }^{15}$ To clarify it, we did another two tests using the DFT-D3 method with the interlayer distances fixed at 3.31 and $3.2 \AA$, respectively, according the previous work. ${ }^{15}$ As shown in Figure S4a, the obtained sliding barriers are in good agreement with that presented in Ref. ${ }^{15}$ The deduced shear stress from the PES also increases with the decrease of $d$ (Figure $\mathrm{S} 4 \mathrm{~b})$.
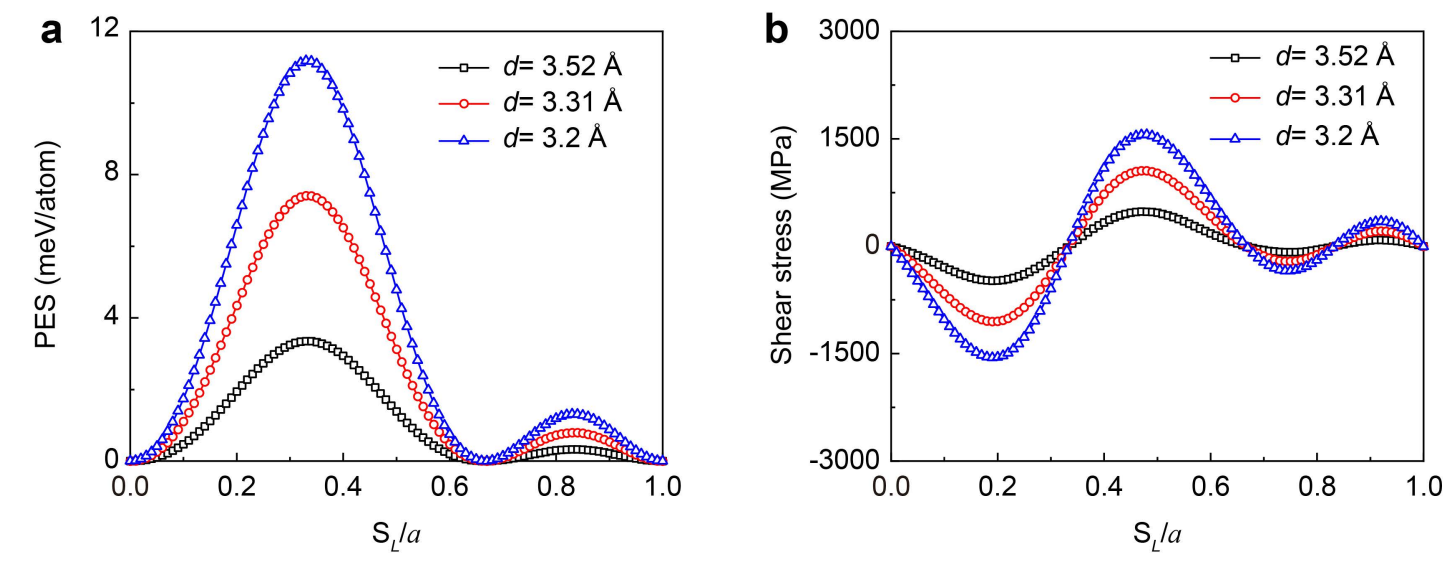

Figure S4. Calculated friction traces using first-principles calculations of bilayer graphene (AB stacking) along the armchair direction with different interlayer distances $(d)$. (a) PES relative to the global energy minimum, and (b) the shear stress as a function of the sliding length $\left(\mathrm{S}_{L}\right)$ were obtained. $d=3.52 \AA$ was the equilibrium distance obtained using the DFT-D3 method. 


\section{5, Heterojunction configurations used in the friction tests and the calculations of surface smoothness}

As shown in Figure S5a-c, the optimized atomic configurations (top and side views) of heterojunctions correspond to the friction traces in Figure 5b-d. In addition, the friction test of the relaxed $\mathrm{C}_{2} / \mathrm{Sc}_{3} \mathrm{C}_{2}$ heterojunction (Figure $\mathrm{S} 3 \mathrm{~b}$ ) with binding energy $\left(1.29 \mathrm{~J} / \mathrm{m}^{2}\right.$ ) was also implemented (Figure 5e). The friction test was performed with the top layer sliding along the direction of the minimum in-plane stiffness $\left(E_{\min }\right)$. By comparing the in-plane stiffness of the 2D materials, the $E_{\min }$ of these heterojunctions (Figure S5 and Figure $\mathrm{S} 3 \mathrm{~b}$ ) is from that of $\mathrm{Sc}_{3} \mathrm{C}_{2}$ and $\mathrm{P}_{2}$, respectively. Considering the in-plane isotropic nature of $\mathrm{Sc}_{3} \mathrm{C}_{2}$ and $\mathrm{P}_{2}$, the sliding direction was chosen along $a$ direction of the lattice, corresponding to the $x$ axis.

To investigate the surface smoothness, the altitude difference $(\Delta h)$ along out-of-plane direction between atoms for the considered 2D materials were measured. As shown in Figure 2, the considered 2D materials can be divided into three categories with respect to the atomic layers: i), the single-atomic-layer structures (e.g, the graphene and $h$-BN); ii), the diatomiclayer structures (e.g., the $\mathrm{P}_{2}$ and $\mathrm{As} 4$ ); iii), polyatomic-layer structures (e.g, the $2 \mathrm{H}-\mathrm{MoS}_{2}$ and $\mathrm{Sc}_{3} \mathrm{C}_{2}$ ). For the multiatomic-layer and diatomic-layer structures (e.g., the $\mathrm{Sc}_{3} \mathrm{C}_{2}$ and $\mathrm{P}_{2}$ ), the $\Delta h$ is measured as the altitude difference between the surface and subsurface atoms as depicted in Figure S5a-b. For the single-atomic-layer structures (e.g, the graphene and $h$-BN), the $\Delta h$ is zero. The measured $\Delta h$ of these considered 2D materials is shown in Figure $5 \mathrm{f}$ in the main text. 
a
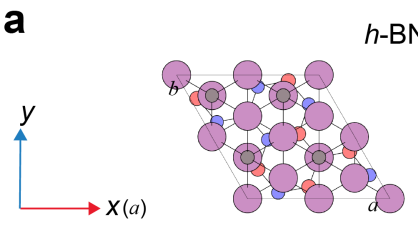

C
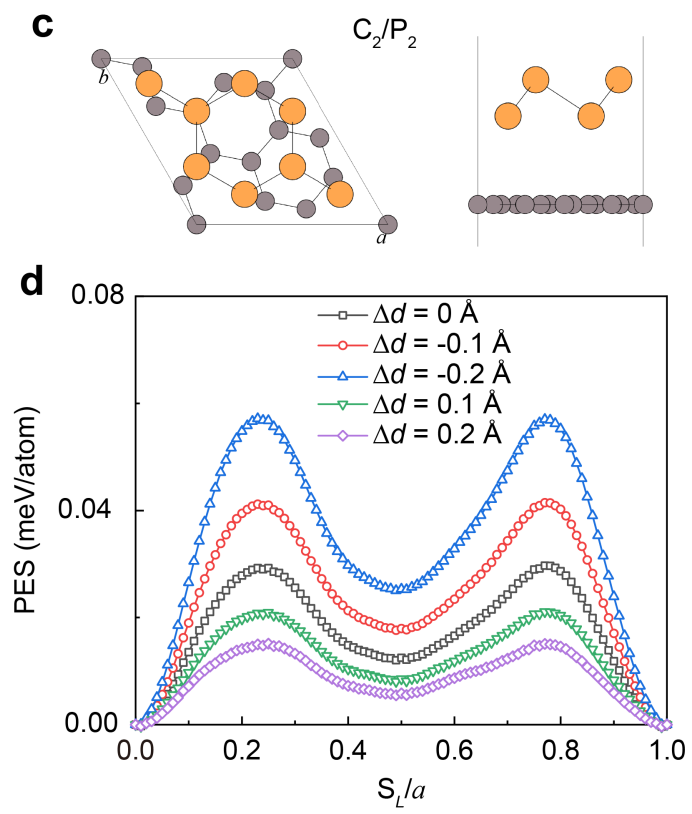

b
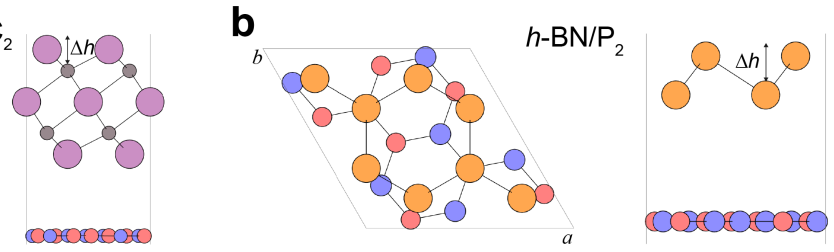

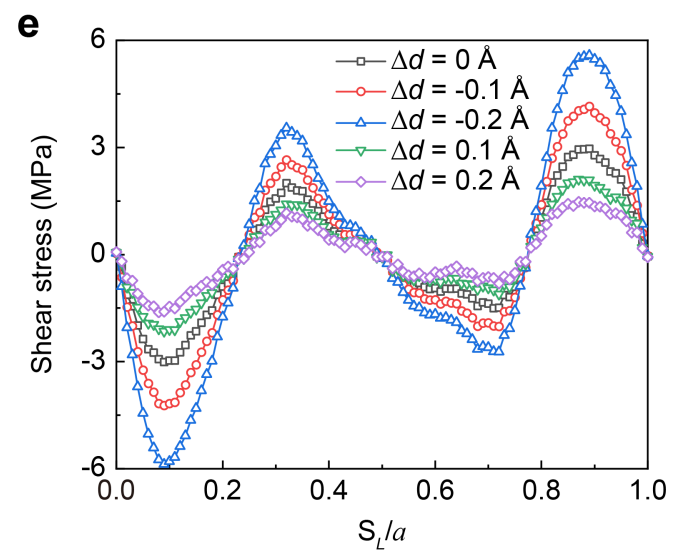

Figure S5. Top (left) and side (right) views of (a) $h$-BN/Sc $\mathrm{SC}_{2}$, (b) $h-\mathrm{BN} / \mathrm{P}_{2}$ and (c) $\mathrm{C}_{2} / \mathrm{P}_{2}$ heterojunctions for the calculations of friction traces using first-principles calculations, corresponding to the results shown in Figure $5 \mathrm{~b}-\mathrm{d}$. The procedure was implemented by moving one layer sliding over the other layer along the $x$ direction. $\Delta h$ is the altitude difference along out-of-plane direction between atoms for considered 2D materials. (d-e) Calculated friction traces using first-principles calculations of the $\mathrm{C}_{2} / \mathrm{P}_{2}$ heterojunction with different interlayer distances. $\Delta d$ is the change of layer spacing with respect to the equilibrium configuration. (d) PES relative to the global energy minimum, and (e) the shear stress as a function of the sliding length $\left(\mathrm{S}_{L}\right)$. 


\section{6, The influences of the relative orientation and sliding direction on the friction}

Herein, we investigate the influence of the relative orientation. ${ }^{2,16-18}$ The relative orientation can be described by the misfit angle $(\theta)$ between the two layers in heterojunction. Since a large number of heterojunctions were considered in this work and it would be a huge task to systematically study these influences for each heterojunction. Herein, we take the $C_{2} / P_{2}$ heterojunction with different misfit angles as a case to investigate the influences of the relative orientation (Figure S6a). After structural optimizations, the friction traces using first-principles calculations were performed along the $x$ direction. The obtained results of friction traces are shown in Figure S6c-d. The results of friction trace of the $\mathrm{C}_{2} / \mathrm{P}_{2}$ with the misfit angle of $19.11^{\circ}$ has been shown in Figure 5d. The statistics average friction stress for the four heterojunctions shows in Figure S7a, demonstrating that the average friction stress decreases (9.90-1.46 MPa) with the increase of the misfit angle. This phenomenon has also been observed in previous work on graphene/ $h$-BN heterojunction. ${ }^{2,19,20}$

On the other hand, the influence of the sliding direction between the sliding layers is also of importance. We take the $\mathrm{C}_{2} / \mathrm{P}_{2}$ heterojunction with the misfit angle of $19.11^{\circ}$ as an example to investigate the influence of the sliding direction on the friction. First, the sliding was performed along the $y$ direction (Figure S5c) with a sliding step of $\Delta \mathrm{S}_{L} / b^{*}=0.1\left(b^{*}\right.$ represents the period length of the $2 \mathrm{D}$ heterojunction lattice along the $y$ direction). Then ten structures at equal intervals along the $y$ direction were obtained. Starting with the each obtained structure, the sliding along the $x$ direction with a sliding step of $\Delta \mathrm{S}_{L} / a=0.01$ was performed. Finally, a thousand sliding points in the area at the interface between $\mathrm{C}_{2}$ and $\mathrm{P}_{2}$ were obtained. The obtained sliding PES was illustrated in Figure S7b, showing that the maximum sliding energy barrier is $0.0325 \mathrm{meV} /$ atom that is only slightly larger than that $(0.0297 \mathrm{meV} /$ atom $)$ in Figure $5 \mathrm{~d}$. This result indicates that the influence of the sliding direction on friction trace of is quite small. 

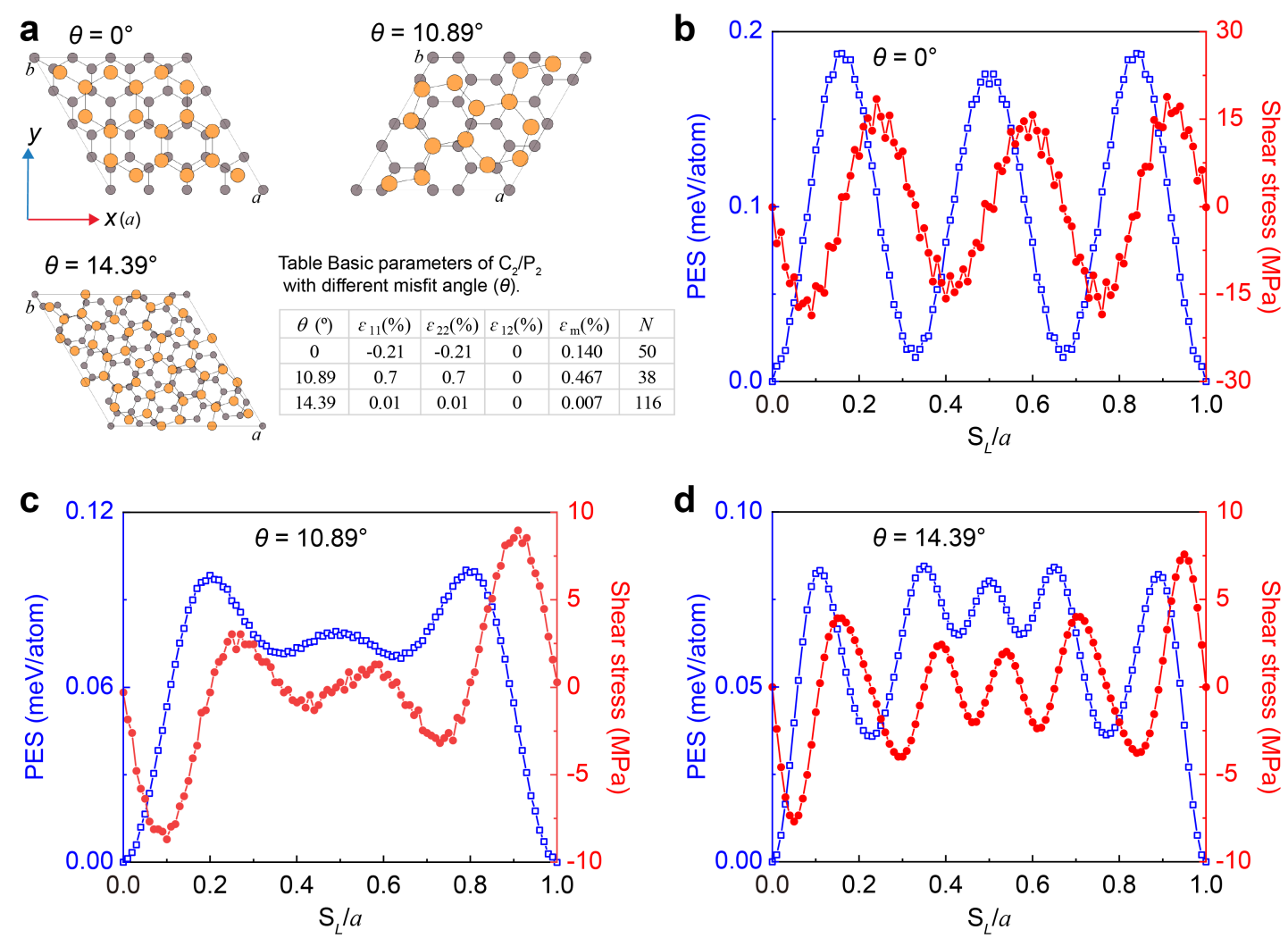

Figure S6. (a) Top views of the $\mathrm{C}_{2} / \mathrm{P}_{2}$ heterojunctions with the misfit angles of $0^{\circ}, 10.89^{\circ}$, and $14.39^{\circ}$. The inset table in panel (a) gives the basic parameters for constructing $\mathrm{C}_{2} / \mathrm{P}_{2}$ heterojunctions. The corresponding calculated friction traces were shown in (b-d). The procedure was implemented by moving one layer sliding over the other layer along the $x$ direction, respectively.

a

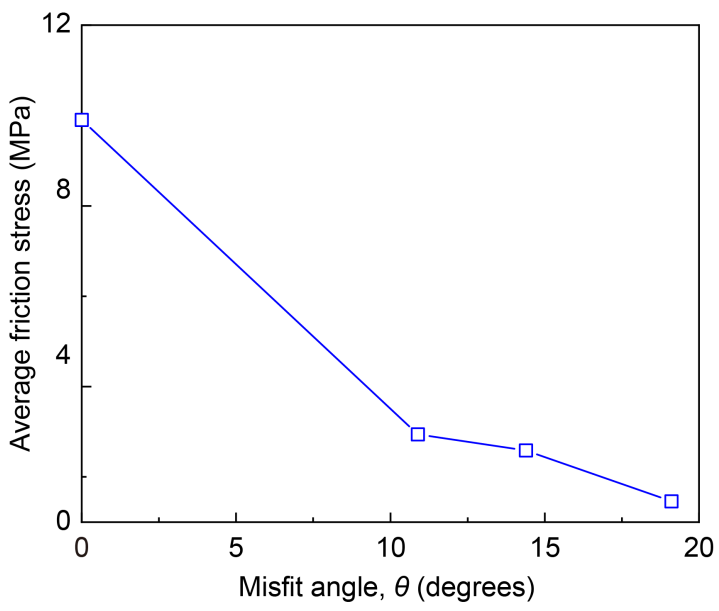

b

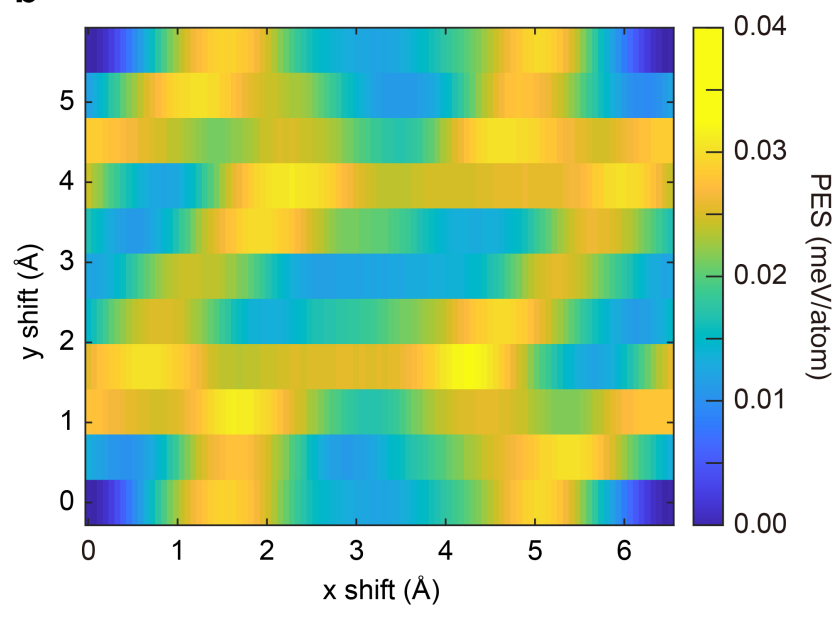


Figure S7. Influences of (a) the relative orientation and (b) sliding direction between the $\mathrm{C}_{2} / \mathrm{P}_{2}$ heterojunction. 
Table S2. $\Gamma_{\mathrm{b}}, E_{\min }, E_{\min } / \Gamma_{\mathrm{b}}, \varepsilon_{\mathrm{m}}, \varepsilon_{11}, \varepsilon_{22}, \varepsilon_{12}$ and the total atoms $(N)$ of $2 \mathrm{D}$ heterojunctions, and $\mathrm{C}_{2} / \mathrm{C}_{2}$ and $\mathrm{MoS}_{2} / \mathrm{MoS}_{2}$ bilayer.

\begin{tabular}{|c|c|c|c|c|c|c|c|c|}
\hline & $\Gamma_{\mathrm{b}}$ & $E_{\min }$ & $E_{\min } / \Gamma_{\mathrm{b}}$ & $\varepsilon_{11}$ & $\varepsilon_{22}$ & $\varepsilon_{12}$ & $\varepsilon_{\mathrm{m}}$ & $N$ \\
\hline $\mathrm{C}_{2}-\mathrm{AB}$ & 0.27 & 340.47 & 1266.4 & / & / & / & / & 4 \\
\hline $\mathrm{C}_{2} / h-\mathrm{BN}$ & 0.30 & 275.07 & 927.5 & -0.91 & -0.91 & 0.00 & 0.61 & 4 \\
\hline$h-\mathrm{BN} / \mathrm{Sc}_{3} \mathrm{C}_{2}$ & 0.24 & 155.29 & 645.7 & 0.87 & 0.87 & 0.00 & 0.58 & 34 \\
\hline$h-\mathrm{BN} / \mathrm{B}_{4}$ & 0.24 & 155.84 & 641.0 & 0.19 & -0.17 & 0.03 & 0.13 & 76 \\
\hline$h-\mathrm{BN} / \mathrm{B}_{5}$ & 0.26 & 165.15 & 638.4 & 0.49 & -0.42 & 0.00 & 0.30 & 31 \\
\hline$h-\mathrm{BN} / \mathrm{Ti}_{3} \mathrm{C}_{2}$ & 0.36 & 224.18 & 629.3 & 1.29 & 1.29 & 0.00 & 0.86 & 71 \\
\hline $\mathrm{C}_{2} / \mathrm{Mo}_{2} \mathrm{C}$ & 0.19 & 115.58 & 624.7 & -0.05 & -0.05 & 0.00 & 0.03 & 34 \\
\hline $\mathrm{C}_{2} / \mathrm{B}_{4}$ & 0.28 & 155.84 & 566.0 & -0.81 & -0.88 & -0.01 & 0.57 & 44 \\
\hline$h-\mathrm{BN} / \mathrm{P}_{2}$ & 0.14 & 77.50 & 554.0 & -0.72 & -0.72 & 0.00 & 0.48 & 22 \\
\hline $\mathrm{C}_{2} / \mathrm{B}_{5}$ & 0.30 & 165.15 & 541.7 & 1.39 & -1.32 & 0.00 & 0.90 & 31 \\
\hline $\mathrm{C}_{2} / \mathrm{B}_{2}$ & 0.30 & 160.00 & 525.2 & 0.48 & 0.22 & 0.59 & 0.43 & 30 \\
\hline $\mathrm{C}_{2} / \mathrm{Ti}_{2} \mathrm{C}$ & 0.35 & 130.61 & 369.5 & 1.13 & -1.13 & 0.00 & 0.75 & 53 \\
\hline$h-\mathrm{BN} / \mathrm{Ti}_{2} \mathrm{C}$ & 0.35 & 130.61 & 368.3 & 0.24 & 0.24 & 0.00 & 0.16 & 53 \\
\hline$h-\mathrm{BN} / 2 \mathrm{H}-\mathrm{MoS}_{2}$ & 0.35 & 126.01 & 363.1 & 0.27 & 0.27 & 0.00 & 0.18 & 74 \\
\hline $\mathrm{Ga}_{2} \mathrm{~S}_{2} / \mathrm{P}_{2}$ & 0.22 & 77.40 & 358.9 & 1.26 & 1.26 & 0.00 & 0.84 & 92 \\
\hline $2 \mathrm{H}-\mathrm{MoS}_{2} / \mathrm{B}_{4}$ & 0.35 & 126.01 & 358.0 & 0.00 & -0.07 & -0.01 & 0.03 & 41 \\
\hline $\mathrm{Ga}_{2} \mathrm{~S}_{2}-3 / \mathrm{P}_{2}$ & 0.22 & 74.30 & 344.9 & 1.12 & 1.12 & 0.00 & 0.75 & 92 \\
\hline$h-\mathrm{BN} / \mathrm{B}_{2}$ & 0.47 & 160.00 & 338.2 & -0.14 & 0.36 & 0.68 & 0.39 & 26 \\
\hline $\mathrm{Ga}_{2} \mathrm{~S}_{2} / h-\mathrm{BN}$ & 0.24 & 78.87 & 331.9 & 0.05 & 0.05 & 0.00 & 0.03 & 98 \\
\hline $\mathrm{Ga}_{2} \mathrm{Se}_{2} / \mathrm{Ga}_{2} \mathrm{~S}_{2}$ & 0.20 & 66.10 & 324.5 & 0.35 & 0.55 & 1.30 & 0.73 & 168 \\
\hline $\mathrm{Ga}_{2} \mathrm{Se}_{2} / \mathrm{Ga}_{2} \mathrm{~S}_{2-3}$ & 0.21 & 66.10 & 320.4 & -0.34 & -0.43 & 1.32 & 0.70 & 168 \\
\hline $\mathrm{Ga}_{2} \mathrm{~S}_{2}-3 / h-\mathrm{BN}$ & 0.24 & 74.30 & 312.5 & -0.09 & -0.09 & 0.00 & 0.06 & 98 \\
\hline $2 \mathrm{H}-\mathrm{MoS}_{2} / \mathrm{B}_{5}$ & 0.41 & 126.01 & 305.1 & 1.06 & -1.10 & 0.03 & 0.73 & 79 \\
\hline $\mathrm{Ga}_{2} \mathrm{~S}_{2}-3 / \mathrm{Bi}_{2} \mathrm{Se}_{3}$ & 0.20 & 61.42 & 301.6 & -0.42 & -0.42 & 0.00 & 0.28 & 62 \\
\hline $\mathrm{Ga}_{2} \mathrm{~S}_{2} / \mathrm{Ga}_{2} \mathrm{~S}_{2}-3$ & 0.25 & 74.30 & 296.5 & 0.14 & 0.14 & 0.00 & 0.09 & 16 \\
\hline $\mathrm{P}_{2} / \mathrm{B}_{5}$ & 0.27 & 77.40 & 288.9 & -0.45 & -0.42 & -0.03 & 0.30 & 66 \\
\hline $2 \mathrm{H}-\mathrm{MoS}_{2}-\mathrm{AB}$ & 0.44 & 126.01 & 287.4 & 0.00 & 0.00 & 0.00 & 0.00 & 6 \\
\hline $\mathrm{Ga}_{2} \mathrm{Se}_{2} / h-\mathrm{BN}$ & 0.23 & 66.10 & 286.0 & -0.50 & -0.50 & 0.00 & 0.33 & 34 \\
\hline
\end{tabular}




\begin{tabular}{|c|c|c|c|c|c|c|c|c|}
\hline$h-\mathrm{BN} / \mathrm{P}_{4}$ & 0.08 & 21.85 & 282.4 & -0.38 & 0.96 & -1.29 & 0.88 & 38 \\
\hline $\mathrm{Ga}_{2} \mathrm{Se}_{2} / \mathrm{P}_{2}$ & 0.24 & 66.10 & 279.7 & -0.31 & 0.31 & 0.00 & 0.21 & 40 \\
\hline $\mathrm{P}_{2} / \mathrm{B}_{4}$ & 0.28 & 77.40 & 276.9 & 1.26 & -1.32 & 0.02 & 0.87 & 26 \\
\hline $\mathrm{Ga}_{2} \mathrm{~S}_{2}-3 / \mathrm{C}_{2}$ & 0.27 & 74.30 & 274.9 & 0.93 & 0.93 & 0.00 & 0.62 & 34 \\
\hline $\mathrm{Ga}_{2} \mathrm{~S}_{2} / \mathrm{Bi}_{2} \mathrm{Se}_{3}$ & 0.22 & 61.42 & 274.4 & -0.28 & -0.28 & 0.00 & 0.19 & 62 \\
\hline $\mathrm{P}_{2} / 2 \mathrm{H}-\mathrm{MoS}_{2}$ & 0.29 & 77.40 & 268.1 & 0.49 & 0.49 & 0.00 & 0.33 & 63 \\
\hline$h-\mathrm{BN} / 1 \mathrm{~T}-\mathrm{MoS}_{2}$ & 0.34 & 90.90 & 265.6 & 0.29 & 0.29 & 0.00 & 0.19 & 74 \\
\hline $\mathrm{Bi}_{2} \mathrm{Te}_{3} / \mathrm{C}_{2}$ & 0.19 & 49.87 & 263.5 & 0.33 & 0.33 & 0.00 & 0.22 & 46 \\
\hline $\mathrm{Ga}_{2} \mathrm{Se}_{2} / \mathrm{Bi}_{2} \mathrm{Se}_{3}$ & 0.23 & 61.42 & 261.8 & 0.13 & -1.02 & -1.02 & 0.72 & 232 \\
\hline $\mathrm{Bi}_{2} \mathrm{Se}_{3} / h-\mathrm{BN}$ & 0.24 & 61.42 & 261.0 & 0.60 & -2.26 & 0.00 & 0.95 & 128 \\
\hline $\mathrm{Bi}_{2} \mathrm{Se}_{3} / \mathrm{P}_{2}$ & 0.24 & 61.42 & 257.0 & -0.44 & 0.08 & -2.27 & 0.93 & 82 \\
\hline $\mathrm{Ga}_{2} \mathrm{Se}_{2} / \mathrm{C}_{2}$ & 0.26 & 66.10 & 256.3 & -1.41 & -1.41 & 0.00 & 0.94 & 34 \\
\hline $\mathrm{Bi}_{2} \mathrm{Se}_{3} / \mathrm{C}_{2}$ & 0.24 & 61.42 & 256.2 & 1.35 & -1.35 & 0.00 & 0.90 & 22 \\
\hline $\mathrm{C}_{2} / 1 \mathrm{~T}-\mathrm{MoS}_{2}$ & 0.36 & 90.90 & 254.6 & -1.32 & -1.32 & 0.00 & 0.88 & 26 \\
\hline $\mathrm{Ga}_{2} \mathrm{Te}_{2} / \mathrm{Ga}_{2} \mathrm{~S}_{2}-3$ & 0.21 & 53.60 & 253.2 & 0.76 & 0.76 & 0.00 & 0.51 & 56 \\
\hline $\mathrm{P}_{2} / 1 \mathrm{~T}-\mathrm{MoS}_{2}$ & 0.31 & 77.40 & 251.8 & 0.50 & 0.50 & 0.00 & 0.33 & 63 \\
\hline $\mathrm{Ga}_{2} \mathrm{Te}_{2} / \mathrm{Ga}_{2} \mathrm{~S}_{2}$ & 0.21 & 53.60 & 250.0 & 0.62 & 0.62 & 0.00 & 0.41 & 56 \\
\hline $\mathrm{C}_{2} / \mathrm{Si}_{2}$ & 0.25 & 61.39 & 245.5 & 1.28 & 1.28 & 0.00 & 0.85 & 20 \\
\hline $\mathrm{Ga}_{2} \mathrm{Te}_{2} / h-\mathrm{BN}$ & 0.22 & 53.60 & 244.4 & -1.14 & -1.14 & 0.00 & 0.76 & 110 \\
\hline$h-\mathrm{BN} / \mathrm{Mo}_{2} \mathrm{C}$ & 0.48 & 115.58 & 241.3 & -0.04 & 0.04 & 0.00 & 0.03 & 39 \\
\hline$h-\mathrm{BN} / \mathrm{Si}_{2}$ & 0.26 & 61.39 & 240.7 & 0.38 & 0.38 & 0.00 & 0.25 & 20 \\
\hline $\mathrm{Bi}_{2} \mathrm{Te}_{3} / \mathrm{P}_{2}$ & 0.21 & 49.87 & 238.0 & -0.97 & 0.97 & 0.00 & 0.65 & 34 \\
\hline $\mathrm{Ga}_{2} \mathrm{Te}_{2} / \mathrm{C}_{2}$ & 0.23 & 53.60 & 236.7 & -0.81 & -0.81 & 0.00 & 0.54 & 132 \\
\hline $\mathrm{Ga}_{2} \mathrm{Se}_{2} / \mathrm{Bi}_{2} \mathrm{Te}_{3}$ & 0.22 & 49.87 & 231.4 & 0.26 & 0.26 & 0.00 & 0.17 & 62 \\
\hline $\mathrm{Ga}_{2} \mathrm{Te}_{2} / \mathrm{P}_{2}$ & 0.23 & 53.60 & 231.1 & -0.11 & -0.11 & 0.00 & 0.07 & 86 \\
\hline $\mathrm{Bi}_{2} \mathrm{Te}_{3} / h-\mathrm{BN}$ & 0.23 & 49.87 & 221.5 & 0.77 & -0.77 & 0.00 & 0.51 & 22 \\
\hline $\mathrm{C}_{2} / 2 \mathrm{H}-\mathrm{MoS}_{2}$ & 0.58 & 126.01 & 218.1 & -1.33 & -1.33 & 0.00 & 0.89 & 26 \\
\hline $\mathrm{Ga}_{2} \mathrm{~S}_{2}-3 / \mathrm{Bi}_{2} \mathrm{Te}_{3}$ & 0.23 & 49.87 & 217.5 & 0.60 & 0.60 & 0.00 & 0.40 & 194 \\
\hline $\mathrm{Ga}_{2} \mathrm{~S}_{2} / \mathrm{Bi}_{2} \mathrm{Te}_{3}$ & 0.23 & 49.87 & 217.4 & 0.74 & 0.74 & 0.00 & 0.49 & 194 \\
\hline $\mathrm{P}_{2} / \mathrm{Si}_{2}$ & 0.29 & 61.39 & 209.4 & 1.10 & 1.10 & 0.00 & 0.73 & 14 \\
\hline $\mathrm{P}_{2} / \mathrm{B}_{2}$ & 0.37 & 77.40 & 209.0 & 0.64 & -0.74 & 0.00 & 0.46 & 12 \\
\hline
\end{tabular}




\begin{tabular}{|c|c|c|c|c|c|c|c|c|}
\hline $\mathrm{Bi}_{2} \mathrm{Te}_{3} / \mathrm{Bi}_{2} \mathrm{Se}_{3}$ & 0.25 & 49.87 & 198.8 & -0.19 & -1.09 & -1.30 & 0.86 & 210 \\
\hline $\mathrm{Ga}_{2} \mathrm{Te}_{2} / \mathrm{Bi}_{2} \mathrm{Se}_{3}$ & 0.29 & 53.60 & 182.2 & 0.33 & 0.33 & 0.00 & 0.22 & 18 \\
\hline $\mathrm{Cu}_{2} \mathrm{I}_{2} / \mathrm{Bi}_{2} \mathrm{Se}_{3}$ & 0.21 & 32.89 & 160.4 & 0.17 & 0.17 & 0.00 & 0.11 & 18 \\
\hline $\mathrm{C}_{2} / \mathrm{P}_{2}$ & 0.51 & 77.40 & 152.7 & 0.19 & 0.19 & 0.00 & 0.13 & 22 \\
\hline $\mathrm{Cu}_{2} \mathrm{I}_{2} / h-\mathrm{BN}$ & 0.23 & 32.89 & 141.1 & -1.31 & -1.31 & 0.00 & 0.87 & 110 \\
\hline $\mathrm{Si}_{2} / 1 \mathrm{~T}-\mathrm{MoS}_{2}$ & 0.45 & 61.39 & 135.7 & -0.30 & -0.30 & 0.00 & 0.20 & 83 \\
\hline $\mathrm{Si}_{2} / 2 \mathrm{H}-\mathrm{MoS}_{2}$ & 0.45 & 61.39 & 135.7 & -0.32 & -0.32 & 0.00 & 0.21 & 83 \\
\hline $\mathrm{Ga}_{2} \mathrm{~S}_{2} / \mathrm{Cu}_{2} \mathrm{I}_{2}$ & 0.25 & 32.89 & 133.4 & -0.45 & -0.45 & 0.00 & 0.30 & 56 \\
\hline $\mathrm{Ga}_{2} \mathrm{~S}_{2}-3 / \mathrm{Cu}_{2} \mathrm{I}_{2}$ & 0.25 & 32.89 & 132.2 & -0.60 & -0.60 & 0.00 & 0.40 & 56 \\
\hline $\mathrm{Ga}_{2} \mathrm{Se}_{2} / \mathrm{Cu}_{2} \mathrm{I}_{2}$ & 0.25 & 32.89 & 132.1 & 0.80 & 0.00 & 1.04 & 0.61 & 208 \\
\hline $\mathrm{Cu}_{2} \mathrm{I}_{2} / \mathrm{C}_{2}$ & 0.25 & 32.89 & 131.2 & -0.98 & -0.98 & 0.00 & 0.65 & 132 \\
\hline $\mathrm{Bi}_{2} / \mathrm{C}_{2}$ & 0.20 & 25.15 & 126.1 & -0.71 & 0.71 & 0.00 & 0.47 & 8 \\
\hline $\mathrm{Cu}_{2} \mathrm{I}_{2} / \mathrm{Bi}_{2} \mathrm{Te}_{3}$ & 0.26 & 32.89 & 126.1 & 0.37 & -1.27 & -1.30 & 0.98 & 188 \\
\hline $\mathrm{Cu}_{2} \mathrm{I}_{2} / \mathrm{P}_{2}$ & 0.27 & 32.89 & 121.8 & -0.27 & 0.25 & -2.27 & 0.93 & 72 \\
\hline $\mathrm{Cu}_{2} \mathrm{Te}_{2} / \mathrm{CdCl}_{2}$ & 0.20 & 24.30 & 120.4 & 1.10 & -0.87 & 0.00 & 0.66 & 58 \\
\hline $\mathrm{C}_{2} / \mathrm{Sc}_{3} \mathrm{C}_{2}$ & 1.29 & 155.29 & 120.1 & 0.28 & -0.28 & 0.00 & 0.19 & 61 \\
\hline $\mathrm{Ga}_{2} \mathrm{~S}_{2} / \mathrm{CdCl}_{2}$ & 0.22 & 25.50 & 118.1 & -0.48 & -1.37 & -1.02 & 0.96 & 180 \\
\hline $\mathrm{Ga}_{2} \mathrm{~S}_{2}-3 / \mathrm{CdCl}_{2}$ & 0.22 & 25.50 & 117.8 & 1.36 & 1.36 & 0.00 & 0.91 & 110 \\
\hline $\mathrm{C}_{2} / \mathrm{Ti}_{3} \mathrm{C}_{2}$ & 1.91 & 224.18 & 117.5 & 0.22 & 0.22 & 0.00 & 0.15 & 98 \\
\hline $\mathrm{CdCl}_{2} / \mathrm{Bi}_{2} \mathrm{Te}_{3}$ & 0.22 & 25.50 & 116.4 & 0.72 & 0.72 & 0.00 & 0.48 & 82 \\
\hline $\mathrm{Ga}_{2} \mathrm{Se}_{2} / \mathrm{CdCl}_{2}$ & 0.23 & 25.50 & 110.5 & -0.07 & 0.07 & 0.00 & 0.05 & 48 \\
\hline$h-\mathrm{BN} / \mathrm{Bi}_{2}$ & 0.23 & 25.15 & 109.6 & -0.20 & -0.20 & 0.00 & 0.13 & 8 \\
\hline $\mathrm{Ga}_{2} \mathrm{Te}_{2} / \mathrm{Bi}_{2}$ & 0.24 & 25.15 & 106.2 & -0.44 & -0.47 & -1.30 & 0.74 & 128 \\
\hline $\mathrm{Cu}_{2} \mathrm{Te}_{2} / h-\mathrm{BN}$ & 0.23 & 24.30 & 105.8 & -2.16 & 0.59 & -0.09 & 0.95 & 60 \\
\hline $\mathrm{Bi}_{2} / \mathrm{P}_{2}$ & 0.25 & 25.15 & 102.2 & -0.01 & -0.01 & 0.00 & 0.01 & 22 \\
\hline $1 \mathrm{~T}-\mathrm{MoS}_{2} / \mathrm{B}_{2}$ & 0.89 & 90.897 & 101.7 & 0.76 & -2.14 & 0.00 & 0.97 & 7 \\
\hline $\mathrm{CdCl}_{2} / h-\mathrm{BN}$ & 0.26 & 25.50 & 100.0 & 0.47 & 0.47 & 0.00 & 0.31 & 26 \\
\hline $\mathrm{CdCl}_{2} / \mathrm{P}_{2}$ & 0.26 & 25.50 & 99.9 & -0.24 & -0.25 & 0.00 & 0.16 & 10 \\
\hline $\mathrm{Cu}_{2} \mathrm{Te}_{2} / \mathrm{C}_{2}$ & 0.25 & 24.30 & 98.6 & 0.03 & -2.17 & 0.00 & 0.73 & 82 \\
\hline $\mathrm{Ga}_{2} \mathrm{~S}_{2} / \mathrm{Bi}_{2}$ & 0.26 & 25.15 & 98.5 & -0.22 & -0.22 & 0.00 & 0.15 & 140 \\
\hline $\mathrm{Ga}_{2} \mathrm{~S}_{2}-3 / \mathrm{Bi}_{2}$ & 0.26 & 25.15 & 97.0 & -0.36 & -0.36 & 0.00 & 0.24 & 140 \\
\hline
\end{tabular}




\begin{tabular}{|c|c|c|c|c|c|c|c|c|}
\hline $\mathrm{Ga}_{2} \mathrm{~S}_{2}-3 / \mathrm{Cu}_{2} \mathrm{Te}_{2}$ & 0.26 & 24.30 & 94.3 & 2.25 & 0.57 & -0.12 & 0.98 & 92 \\
\hline $\mathrm{CdCl}_{2} / \mathrm{C}_{2}$ & 0.27 & 25.50 & 92.9 & -0.43 & -0.43 & 0.00 & 0.29 & 26 \\
\hline $2 \mathrm{H}-\mathrm{MoS}_{2} / \mathrm{B}_{2}$ & 1.44 & 126.01 & 87.8 & 2.15 & -0.77 & 0.00 & 0.97 & 14 \\
\hline $\mathrm{Si}_{2} / \mathrm{B}_{4}$ & 0.70 & 61.391 & 87.3 & 2.12 & 0.20 & -0.29 & 0.87 & 64 \\
\hline $\mathrm{Ga}_{2} \mathrm{Te}_{2} / \mathrm{CaI}_{2}$ & 0.19 & 16.58 & 86.5 & 1.12 & 0.22 & -1.30 & 0.88 & 146 \\
\hline $\mathrm{Cu}_{2} \mathrm{Te}_{2} / \mathrm{P}_{4}$ & 0.28 & 24.30 & 86.3 & 0.96 & -1.81 & 0.00 & 0.92 & 44 \\
\hline $\mathrm{Ga}_{2} \mathrm{Se}_{2} / \mathrm{Bi}_{2}$ & 0.29 & 25.15 & 85.6 & -0.70 & -0.70 & 0.00 & 0.47 & 22 \\
\hline $\mathrm{Ga}_{2} \mathrm{~S}_{2}-3 / \mathrm{CaI}_{2}$ & 0.20 & 16.58 & 84.9 & 1.27 & 0.47 & 1.04 & 0.93 & 184 \\
\hline $\mathrm{P}_{2} / \mathrm{P}_{4}$ & 0.26 & 21.85 & 83.9 & -0.87 & -0.05 & -0.28 & 0.40 & 44 \\
\hline $\mathrm{Ga}_{2} \mathrm{Te}_{2} / \mathrm{Cu}_{2} \mathrm{I}_{2}$ & 0.29 & 24.30 & 82.9 & 0.16 & 0.16 & 0.00 & 0.11 & 16 \\
\hline $\mathrm{CdCl}_{2} / \mathrm{P}_{4}$ & 0.26 & 21.85 & 82.8 & 0.09 & 0.54 & 0.00 & 0.21 & 78 \\
\hline $\mathrm{CdCl}_{2} / \mathrm{CaI}_{2}$ & 0.20 & 16.58 & 82.5 & 0.45 & 0.45 & 0.00 & 0.30 & 132 \\
\hline $\mathrm{Ga}_{2} \mathrm{Se}_{2} / \mathrm{Cu}_{2} \mathrm{Te}_{2}$ & 0.30 & 24.30 & 82.2 & -0.07 & -1.42 & 1.16 & 0.88 & 112 \\
\hline $\mathrm{Bi}_{2} \mathrm{Te}_{3} / \mathrm{P}_{4}$ & 0.27 & 21.85 & 81.7 & -0.20 & 1.10 & -1.60 & 0.97 & 112 \\
\hline $\mathrm{Ga}_{2} \mathrm{~S}_{2} / \mathrm{Cu}_{2} \mathrm{Te}_{2}$ & 0.30 & 24.30 & 81.6 & 2.39 & 0.43 & -0.12 & 0.98 & 92 \\
\hline $\mathrm{Cu}_{2} \mathrm{Te}_{2} / \mathrm{P}_{2}$ & 0.30 & 24.30 & 81.6 & 0.62 & -0.15 & -2.05 & 0.94 & 34 \\
\hline $\mathrm{CaI}_{2} / h-\mathrm{BN}$ & 0.20 & 16.58 & 81.0 & -0.57 & -0.57 & 0.00 & 0.38 & 98 \\
\hline $\mathrm{Ga}_{2} \mathrm{Te}_{2} / \mathrm{Cu}_{2} \mathrm{Te}_{2}$ & 0.30 & 24.30 & 80.3 & -0.09 & -0.07 & 2.32 & 0.83 & 120 \\
\hline $\mathrm{Cu}_{2} \mathrm{Te}_{2} / \mathrm{Cu}_{2} \mathrm{I}_{2}$ & 0.30 & 24.30 & 79.8 & -0.46 & -0.08 & 2.24 & 0.93 & 52 \\
\hline $\mathrm{Ga}_{2} \mathrm{Se}_{2} / \mathrm{CaI}_{2}$ & 0.21 & 16.58 & 79.3 & 0.38 & -0.38 & 1.32 & 0.69 & 148 \\
\hline $\mathrm{Ga}_{2} \mathrm{Se}_{2} / \mathrm{P}_{4}$ & 0.28 & 21.85 & 78.9 & 0.03 & -1.57 & 0.00 & 0.53 & 72 \\
\hline $\mathrm{CaI}_{2} / \mathrm{Bi}_{2} \mathrm{Te}_{3}$ & 0.21 & 16.58 & 78.0 & -1.21 & 1.21 & 0.00 & 0.81 & 124 \\
\hline $\mathrm{Cu}_{2} \mathrm{I}_{2} / \mathrm{CaI}_{2}$ & 0.21 & 16.58 & 77.2 & 0.12 & -0.89 & 1.32 & 0.78 & 146 \\
\hline $\mathrm{Ga}_{2} \mathrm{~S}_{2}-3 / \mathrm{P}_{4}$ & 0.28 & 21.85 & 76.8 & -0.62 & 0.53 & 1.62 & 0.92 & 84 \\
\hline $\mathrm{CaI}_{2} / \mathrm{Bi}_{2} \mathrm{Se}_{3}$ & 0.22 & 16.58 & 75.2 & 0.05 & -0.72 & 1.32 & 0.70 & 166 \\
\hline $\mathrm{Bi}_{2} \mathrm{Se}_{3} / \mathrm{P}_{4}$ & 0.29 & 21.85 & 74.9 & -1.05 & -1.80 & -0.01 & 0.95 & 72 \\
\hline $\mathrm{CaI}_{2} / \mathrm{C}_{2}$ & 0.22 & 16.58 & 74.3 & -0.34 & -0.34 & 0.00 & 0.23 & 98 \\
\hline $\mathrm{Cu}_{2} \mathrm{Br}_{2} / \mathrm{Au}_{2} \mathrm{Br}_{2}$ & 0.11 & 7.84 & 72.4 & 0.02 & 0.00 & 0.68 & 0.23 & 68 \\
\hline $\mathrm{Bi}_{2} \mathrm{Se}_{3} / \mathrm{Bi}_{2}$ & 0.35 & 25.15 & 71.8 & 0.06 & -0.70 & 1.32 & 0.69 & 150 \\
\hline $\mathrm{CaI}_{2} / \mathrm{Bi}_{2}$ & 0.23 & 16.58 & 71.7 & -1.08 & -1.08 & 0.00 & 0.72 & 74 \\
\hline $\mathrm{CaI}_{2} / \mathrm{P}_{2}$ & 0.23 & 16.58 & 71.5 & 1.27 & 1.27 & 0.00 & 0.85 & 98 \\
\hline
\end{tabular}




\begin{tabular}{|c|c|c|c|c|c|c|c|c|}
\hline $\mathrm{C}_{2} / \mathrm{P}_{4}$ & 0.31 & 21.85 & 69.7 & -0.40 & -1.30 & -0.05 & 0.58 & 58 \\
\hline $\mathrm{Bi}_{2} \mathrm{Te}_{3} / \mathrm{Bi}_{2}$ & 0.37 & 25.15 & 67.2 & -0.96 & -0.96 & 0.00 & 0.64 & 14 \\
\hline $\mathrm{Ga}_{2} \mathrm{Te}_{2} / \mathrm{P}_{4}$ & 0.33 & 21.85 & 65.9 & -0.71 & -2.14 & -0.01 & 0.95 & 64 \\
\hline $\mathrm{Cu}_{2} \mathrm{Te}_{2} / \mathrm{Bi}_{2}$ & 0.37 & 24.30 & 65.4 & -0.35 & -0.83 & -0.15 & 0.44 & 84 \\
\hline $\mathrm{Bi}_{2} / \mathrm{P}_{4}$ & 0.34 & 21.85 & 64.2 & 1.14 & -0.81 & 0.05 & 0.67 & 82 \\
\hline $\mathrm{CaI}_{2} / \mathrm{P}_{4}$ & 0.26 & 16.58 & 63.6 & -0.46 & -0.04 & 1.99 & 0.83 & 66 \\
\hline $\mathrm{Cu}_{2} \mathrm{I}_{2} / \mathrm{P}_{4}$ & 0.35 & 21.85 & 63.1 & -0.88 & -1.97 & -0.01 & 0.95 & 64 \\
\hline $\mathrm{Cu}_{2} \mathrm{Te}_{2} / \mathrm{CaI}_{2}$ & 0.27 & 16.58 & 62.1 & -2.57 & 0.10 & 0.00 & 0.89 & 60 \\
\hline $\mathrm{Si}_{2} / \mathrm{B}_{5}$ & 1.04 & 61.391 & 59.0 & -0.42 & -0.46 & -0.03 & 0.30 & 44 \\
\hline $\mathrm{Ga}_{2} \mathrm{~S}_{2} / \mathrm{Au}_{2} \mathrm{Br}_{2}$ & 0.20 & 11.00 & 54.8 & 0.41 & 2.21 & 0.00 & 0.87 & 104 \\
\hline $\mathrm{Au}_{2} \mathrm{Br}_{2} / h-\mathrm{BN}$ & 0.20 & 11.00 & 54.7 & 0.02 & -1.93 & 0.66 & 0.87 & 32 \\
\hline $\mathrm{Sc}_{3} \mathrm{C}_{2} / \mathrm{B}_{2}$ & 2.87 & 155.29 & 54.1 & 0.96 & 0.21 & 0.36 & 0.51 & 56 \\
\hline $\mathrm{CaI}_{2} / \mathrm{Au}_{2} \mathrm{Br}_{2}$ & 0.21 & 11.00 & 52.4 & -0.06 & 0.02 & 1.83 & 0.64 & 86 \\
\hline $\mathrm{Au}_{2} \mathrm{Br}_{2} / \mathrm{C}_{2}$ & 0.21 & 11.00 & 51.7 & -0.92 & 1.02 & -0.66 & 0.87 & 32 \\
\hline $\mathrm{Au}_{2} \mathrm{Br}_{2} / \mathrm{P}_{2}$ & 0.22 & 11.00 & 50.8 & -1.04 & 1.32 & 0.25 & 0.87 & 38 \\
\hline $\mathrm{Ga}_{2} \mathrm{Te}_{2} / \mathrm{Au}_{2} \mathrm{Br}_{2}$ & 0.22 & 11.00 & 50.3 & -0.15 & -0.41 & 1.17 & 0.58 & 44 \\
\hline $\mathrm{Cu}_{2} \mathrm{I}_{2} / \mathrm{Au}_{2} \mathrm{Br}_{2}$ & 0.22 & 11.00 & 50.0 & -1.40 & 0.51 & 0.69 & 0.87 & 44 \\
\hline $\mathrm{CdCl}_{2} / \mathrm{Au}_{2} \mathrm{Br}_{2}$ & 0.22 & 11.00 & 49.0 & 1.22 & -0.65 & 0.00 & 0.62 & 94 \\
\hline $\mathrm{Ga}_{2} \mathrm{Se}_{2} / \mathrm{Au}_{2} \mathrm{Br}_{2}$ & 0.23 & 11.00 & 48.8 & -1.38 & -0.62 & -0.72 & 0.91 & 108 \\
\hline $\mathrm{Bi}_{2} \mathrm{Se}_{3} / \mathrm{Au}_{2} \mathrm{Br}_{2}$ & 0.24 & 11.00 & 46.3 & -1.57 & 0.34 & 0.69 & 0.87 & 50 \\
\hline $\mathrm{Cu}_{2} \mathrm{Br}_{2} / \mathrm{CaI}_{2}$ & 0.17 & 7.84 & 46.2 & 1.23 & 0.34 & -0.18 & 0.58 & 92 \\
\hline $\mathrm{Au}_{2} \mathrm{Br}_{2} / \mathrm{P}_{4}$ & 0.24 & 11.00 & 45.8 & 2.21 & 0.22 & 0.42 & 0.95 & 44 \\
\hline $\mathrm{Bi}_{2} \mathrm{Te}_{3} / \mathrm{Au}_{2} \mathrm{Br}_{2}$ & 0.24 & 11.00 & 45.7 & -0.84 & -0.56 & 0.25 & 0.55 & 140 \\
\hline $\mathrm{P}_{2} / \mathrm{Sc}_{3} \mathrm{C}_{2}$ & 1.86 & 77.40 & 41.7 & -0.42 & -0.42 & 0.00 & 0.28 & 86 \\
\hline $\mathrm{CdCl}_{2} / \mathrm{Au}_{2} \mathrm{Se}_{2}$ & 0.22 & 8.78 & 40.1 & -1.44 & 0.09 & 1.41 & 0.98 & 40 \\
\hline$h$-BN/As4 & 0.26 & 10.40 & 39.5 & 1.15 & -0.15 & -0.11 & 0.47 & 92 \\
\hline $\mathrm{As}_{4} / \mathrm{C}_{2}$ & 0.26 & 10.40 & 39.4 & 2.14 & -0.39 & 0.00 & 0.84 & 76 \\
\hline $\mathrm{Au}_{2} \mathrm{Br}_{2} / \mathrm{As}_{4}$ & 0.26 & 10.40 & 39.4 & 0.02 & -0.26 & -2.34 & 0.87 & 48 \\
\hline $\mathrm{Cu}_{2} \mathrm{Br}_{2} / h-\mathrm{BN}$ & 0.20 & 7.84 & 39.3 & 0.98 & -0.94 & 0.96 & 0.96 & 46 \\
\hline $\mathrm{Cu}_{2} \mathrm{I}_{2} / \mathrm{Cu}_{2} \mathrm{Br}_{2}$ & 0.20 & 7.84 & 38.6 & -0.16 & -0.13 & -0.96 & 0.42 & 140 \\
\hline $\mathrm{Cu}_{2} \mathrm{Br}_{2} / \mathrm{C}_{2}$ & 0.20 & 7.84 & 38.5 & 0.08 & -0.04 & 0.96 & 0.36 & 48 \\
\hline
\end{tabular}




\begin{tabular}{|c|c|c|c|c|c|c|c|c|}
\hline $\mathrm{Ti}_{3} \mathrm{C}_{2} / \mathrm{B}_{2}$ & 4.25 & 160.00 & 37.6 & 0.40 & -1.60 & 0.80 & 0.93 & 68 \\
\hline $\mathrm{CaI}_{2} / \mathrm{As}_{4}$ & 0.28 & 10.40 & 37.0 & 0.27 & -1.11 & 0.77 & 0.72 & 110 \\
\hline $\mathrm{Cu}_{2} \mathrm{Te}_{2} / \mathrm{Au}_{2} \mathrm{Br}_{2}$ & 0.30 & 11.00 & 36.8 & 0.73 & 0.27 & 0.10 & 0.37 & 112 \\
\hline $\mathrm{Au}_{2} \mathrm{Br}_{2} / \mathrm{Bi}_{2}$ & 0.30 & 11.00 & 36.8 & 0.12 & -2.01 & -0.57 & 0.90 & 50 \\
\hline $\mathrm{CdCl}_{2} / \mathrm{As}_{4}$ & 0.28 & 10.40 & 36.5 & 0.32 & -1.30 & -0.28 & 0.63 & 94 \\
\hline $\mathrm{Ga}_{2} \mathrm{~S}_{2}-3 / \mathrm{Cu}_{2} \mathrm{Br}_{2}$ & 0.22 & 7.84 & 35.5 & 1.84 & 0.09 & 0.00 & 0.64 & 64 \\
\hline $\mathrm{Cu}_{2} \mathrm{Br}_{2} / \mathrm{P}_{2}$ & 0.22 & 7.84 & 35.2 & -0.52 & 1.01 & 0.59 & 0.71 & 58 \\
\hline $\mathrm{Ga}_{2} \mathrm{Se}_{2} / \mathrm{Au}_{2} \mathrm{Se}_{2}$ & 0.25 & 8.78 & 34.6 & -1.50 & 0.02 & 1.41 & 0.98 & 40 \\
\hline $\mathrm{Bi}_{2} \mathrm{Se}_{3} / \mathrm{Au}_{2} \mathrm{Se}_{2}$ & 0.26 & 8.78 & 34.0 & -0.58 & 0.64 & 1.45 & 0.89 & 82 \\
\hline $\mathrm{Ga}_{2} \mathrm{~S}_{2} / \mathrm{Cu}_{2} \mathrm{Br}_{2}$ & 0.23 & 7.84 & 33.9 & 0.05 & -1.98 & 0.00 & 0.68 & 64 \\
\hline $\mathrm{Ga}_{2} \mathrm{~S}_{2} / \mathrm{As}_{4}$ & 0.31 & 10.40 & 33.6 & 0.95 & 0.23 & 0.00 & 0.39 & 40 \\
\hline $\mathrm{Ga}_{2} \mathrm{~S}_{2}-3 / \mathrm{As}_{4}$ & 0.31 & 10.40 & 33.6 & 0.81 & 0.09 & 0.00 & 0.30 & 40 \\
\hline $\mathrm{Ga}_{2} \mathrm{Te}_{2} / \mathrm{As}_{4}$ & 0.31 & 10.40 & 33.1 & -0.03 & 0.78 & 1.62 & 0.81 & 88 \\
\hline $\mathrm{Cu}_{2} \mathrm{I}_{2} / \mathrm{As}_{4}$ & 0.32 & 10.40 & 33.0 & -0.20 & 0.94 & 1.62 & 0.92 & 88 \\
\hline $\mathrm{Cu}_{2} \mathrm{I}_{2} / \mathrm{Au}_{2} \mathrm{Se}_{2}$ & 0.27 & 8.78 & 33.0 & -0.09 & -2.66 & -0.09 & 0.95 & 104 \\
\hline $\mathrm{CaI}_{2} / \mathrm{Au}_{2} \mathrm{Se}_{2}$ & 0.27 & 8.78 & 32.5 & -1.52 & -1.16 & 0.00 & 0.89 & 24 \\
\hline $\mathrm{Si}_{2} / \mathrm{Mo}_{2} \mathrm{C}$ & 1.89 & 61.39 & 32.4 & -1.33 & -1.33 & 0.00 & 0.89 & 29 \\
\hline $\mathrm{Bi}_{2} \mathrm{Se}_{3} / \mathrm{As}_{4}$ & 0.33 & 10.40 & 31.3 & 0.32 & -0.39 & 0.00 & 0.24 & 118 \\
\hline $\mathrm{Si}_{2} / \mathrm{B}_{2}$ & 1.98 & 61.391 & 31.0 & -1.84 & -0.46 & 0.00 & 0.77 & 22 \\
\hline $\mathrm{As}_{4} / \mathrm{P}_{4}$ & 0.34 & 10.40 & 30.8 & 2.27 & -0.04 & 0.00 & 0.77 & 88 \\
\hline $\mathrm{Si}_{2} / \mathrm{Ti}_{2} \mathrm{C}$ & 2.05 & 61.39 & 30.0 & -0.14 & -0.14 & 0.00 & 0.09 & 89 \\
\hline $\mathrm{Bi}_{2} \mathrm{Te}_{3} / \mathrm{As}_{4}$ & 0.35 & 10.40 & 29.8 & 0.18 & -1.40 & -0.13 & 0.57 & 90 \\
\hline $\mathrm{Ga}_{2} \mathrm{Se}_{2} / \mathrm{As}_{4}$ & 0.35 & 10.40 & 29.8 & 0.26 & -1.85 & -0.28 & 0.80 & 112 \\
\hline $\mathrm{Ti}_{2} \mathrm{C} / \mathrm{B}_{2}$ & 4.48 & 130.61 & 29.1 & 0.27 & -1.65 & 0.00 & 0.64 & 92 \\
\hline $\mathrm{As}_{4} / \mathrm{P}_{2}$ & 0.36 & 10.40 & 28.8 & -0.96 & -1.15 & -0.55 & 0.89 & 38 \\
\hline $\mathrm{Si}_{2} / \mathrm{Sc}_{3} \mathrm{C}_{2}$ & 2.15 & 61.39 & 28.6 & 0.48 & 0.48 & 0.00 & 0.32 & 52 \\
\hline $\mathrm{Cu}_{2} \mathrm{Te}_{2} / \mathrm{As}_{4}$ & 0.37 & 10.40 & 28.2 & -0.27 & 0.51 & 1.05 & 0.61 & 76 \\
\hline $\mathrm{P}_{2} / \mathrm{Mo}_{2} \mathrm{C}$ & 2.75 & 77.40 & 28.2 & 0.16 & -0.16 & 0.00 & 0.11 & 36 \\
\hline $\mathrm{As}_{4} / \mathrm{Bi}_{2}$ & 0.38 & 10.40 & 27.6 & 1.52 & 0.86 & 0.13 & 0.84 & 50 \\
\hline $\mathrm{P}_{2} / \mathrm{Ti}_{3} \mathrm{C}_{2}$ & 2.86 & 77.40 & 27.1 & -0.79 & -0.79 & 0.00 & 0.53 & 89 \\
\hline $\mathrm{Cu}_{2} \mathrm{Br}_{2} / \mathrm{P}_{4}$ & 0.29 & 7.84 & 27.1 & -0.49 & -1.88 & 0.00 & 0.79 & 28 \\
\hline
\end{tabular}




\begin{tabular}{|c|c|c|c|c|c|c|c|c|}
\hline $\mathrm{Cu}_{2} \mathrm{Br}_{2} / \mathrm{As}_{4}$ & 0.39 & 10.40 & 27.0 & -0.66 & 0.69 & -0.99 & 0.78 & 88 \\
\hline $\mathrm{Mo}_{2} \mathrm{C} / \mathrm{B}_{2}$ & 4.71 & 115.58 & 24.5 & 0.48 & -0.90 & 0.00 & 0.46 & 12 \\
\hline $\mathrm{P}_{2} / \mathrm{Ti}_{2} \mathrm{C}$ & 3.16 & 77.40 & 24.5 & 0.45 & -0.45 & 0.00 & 0.30 & 89 \\
\hline $\mathrm{Au}_{2} \mathrm{Se}_{2} / h-\mathrm{BN}$ & 0.46 & 8.78 & 19.0 & -2.01 & -0.75 & -0.09 & 0.95 & 76 \\
\hline $\mathrm{Si}_{2} / \mathrm{Ti}_{3} \mathrm{C}_{2}$ & 3.55 & 61.39 & 17.3 & 0.81 & 0.81 & 0.00 & 0.54 & 119 \\
\hline $\mathrm{Au}_{2} \mathrm{Se}_{2} / \mathrm{C}_{2}$ & 0.54 & 8.78 & 16.3 & 0.42 & 1.39 & 0.83 & 0.88 & 54 \\
\hline $\mathrm{Au}_{2} \mathrm{Se}_{2} / \mathrm{As}_{4}$ & 0.57 & 8.78 & 15.5 & 1.05 & 0.65 & -0.43 & 0.71 & 100 \\
\hline $\mathrm{Au}_{2} \mathrm{Se}_{2} / \mathrm{Au}_{2} \mathrm{Br}_{2}$ & 0.62 & 8.78 & 14.1 & -0.24 & -1.82 & -0.53 & 0.86 & 80 \\
\hline $\mathrm{Au}_{2} \mathrm{Se}_{2} / \mathrm{P}_{2}$ & 0.65 & 8.78 & 13.5 & 0.90 & 0.05 & -0.11 & 0.35 & 88 \\
\hline $\mathrm{Au}_{2} \mathrm{Se}_{2} / \mathrm{P}_{4}$ & 0.65 & 8.78 & 13.4 & -0.84 & 0.77 & 0.00 & 0.54 & 44 \\
\hline $\mathrm{Ag}_{2} \mathrm{I}_{2} / \mathrm{C}_{2}$ & 0.15 & 1.90 & 12.8 & 0.60 & 1.33 & 0.00 & 0.64 & 68 \\
\hline $\mathrm{Ag}_{2} \mathrm{I}_{2} / h-\mathrm{BN}$ & 0.16 & 1.90 & 12.2 & 0.42 & -1.50 & 0.00 & 0.64 & 68 \\
\hline $\mathrm{Bi}_{2} \mathrm{Te}_{3} / \mathrm{Au}_{2} \mathrm{Se}_{2}$ & 0.73 & 8.78 & 12.1 & -2.78 & 0.02 & -0.09 & 0.96 & 68 \\
\hline $\mathrm{CaI}_{2} / \mathrm{Ag}_{2} \mathrm{I}_{2}$ & 0.16 & 1.90 & 11.6 & -0.14 & 1.78 & 0.00 & 0.64 & 94 \\
\hline $\mathrm{Cu}_{2} \mathrm{Br}_{2} / \mathrm{Ag}_{2} \mathrm{I}_{2}$ & 0.17 & 1.90 & 11.4 & 1.01 & 1.01 & 0.00 & 0.67 & 36 \\
\hline $\mathrm{Ag}_{2} \mathrm{I}_{2} / \mathrm{P}_{2}$ & 0.17 & 1.90 & 10.9 & 0.47 & -1.53 & 0.95 & 0.98 & 78 \\
\hline $\mathrm{Ga}_{2} \mathrm{Se}_{2} / \mathrm{Ag}_{2} \mathrm{I}_{2}$ & 0.18 & 1.90 & 10.7 & -0.39 & 1.53 & -0.94 & 0.95 & 108 \\
\hline $\mathrm{Cu}_{2} \mathrm{I}_{2} / \mathrm{Ag}_{2} \mathrm{I}_{2}$ & 0.19 & 1.90 & 10.0 & -0.61 & -0.09 & 0.00 & 0.23 & 88 \\
\hline $\mathrm{Au}_{2} \mathrm{Se}_{2} / \mathrm{Bi}_{2}$ & 0.90 & 8.78 & 9.8 & -0.95 & -1.81 & 0.09 & 0.95 & 44 \\
\hline $\mathrm{Ag}_{2} \mathrm{I}_{2} / \mathrm{P}_{4}$ & 0.19 & 1.90 & 9.8 & -0.43 & -0.21 & -1.18 & 0.61 & 64 \\
\hline $\mathrm{Au}_{2} \mathrm{Br}_{2} / \mathrm{Ag}_{2} \mathrm{I}_{2}$ & 0.20 & 1.90 & 9.7 & 0.96 & 0.29 & -0.26 & 0.50 & 88 \\
\hline $\mathrm{Bi}_{2} \mathrm{Te}_{3} / \mathrm{Ag}_{2} \mathrm{I}_{2}$ & 0.20 & 1.90 & 9.6 & 0.29 & -1.86 & 0.18 & 0.78 & 124 \\
\hline $\mathrm{Ga}_{2} \mathrm{Te}_{2} / \mathrm{Ag}_{2} \mathrm{I}_{2}$ & 0.20 & 1.90 & 9.5 & 0.07 & -1.99 & 0.00 & 0.69 & 64 \\
\hline $\mathrm{Cu}_{2} \mathrm{Te}_{2} / \mathrm{Ag}_{2} \mathrm{I}_{2}$ & 0.20 & 1.90 & 9.4 & 0.38 & 0.59 & 1.16 & 0.71 & 48 \\
\hline $\mathrm{Bi}_{2} \mathrm{Se}_{3} / \mathrm{Ag}_{2} \mathrm{I}_{2}$ & 0.21 & 1.90 & 9.0 & 0.39 & -0.40 & 2.05 & 0.95 & 88 \\
\hline $\mathrm{Ag}_{2} \mathrm{I}_{2} / \mathrm{As}_{4}$ & 0.23 & 1.90 & 8.2 & 0.08 & 0.89 & 0.08 & 0.35 & 100 \\
\hline $\mathrm{Au}_{2} \mathrm{Se}_{2} / \mathrm{Ag}_{2} \mathrm{I}_{2}$ & 0.85 & 1.90 & 2.2 & -0.51 & 0.32 & -0.60 & 0.48 & 68 \\
\hline
\end{tabular}




\section{REFERENCES}

1. Plimpton, S., Fast Parallel Algorithms for Short-range Molecular Dynamics. Journal of Computational Physics 1995, 117 (1), 1-19.

2. Song, Y.; Mandelli, D.; Hod, O.; Urbakh, M.; Ma, M.; Zheng, Q., Robust Microscale Duperlubricity in Graphite/Hexagonal Boron Nitride Layered Heterojunctions. Nature Materials 2018, 17 (10), 894-899.

3. Brenner, D. W.; Shenderova, O. A.; Harrison, J. A.; Stuart, S. J.; Ni, B.; Sinnott, S. B., A Second-generation Reactive Empirical Bond Order (REBO) Potential Energy Expression for Hydrocarbons. Journal of Physics: Condensed Matter 2002, 14 (4), 783-802.

4. Kolmogorov, A. N.; Crespi, V. H., Registry-Dependent Interlayer Potential for Graphitic Systems. Physical Review B 2005, 71 (23), 235415.

5. Iwata, T.; Shintani, K., Reduction of the Thermal Conductivity of a Graphene $/ h$-BN Heterobilayer via Interlayer $s p^{3}$ Bonds. Physical Chemistry Chemical Physics 2018, 20 (7), 5217-5226.

6. Bitzek, E.; Koskinen, P.; Gähler, F.; Moseler, M.; Gumbsch, P., Structural Relaxation Made Simple. Physical Review Letters 2006, 97 (17), 170201.

7. Koda, D. S.; Bechstedt, F.; Marques, M.; Teles, L. K., Coincidence Lattices of 2D Crystals: Heterostructure Predictions and Applications. The Journal of Physical Chemistry C 2016, 120 (20), 10895-10908.

8. Zur, A.; McGill, T. C., Lattice Match: An Application to Heteroepitaxy. Journal of Applied Physics 1984, 55 (2), 378-386.

9. Liu, J.; Cheng, B.; Yu, J., A New Understanding of the Photocatalytic Mechanism of the Direct Z-scheme g- $\mathrm{C}_{3} \mathrm{~N}_{4} / \mathrm{TiO}_{2}$ Heterostructure. Physical Chemistry Chemical Physics 2016, 18 (45), 31175-31183.

10. Grimme, S.; Antony, J.; Ehrlich, S.; Krieg, H., A Consistent and Accurate Ab Initio Parametrization of Density Functional Dispersion Correction (DFT-D) for the 94 Elements $\mathrm{H}-\mathrm{Pu}$. The Journal of Chemical Physics 2010, 132 (15), 154104.

11. Klimeš, J.; Bowler, D. R.; Michaelides, A., Chemical Accuracy for the Van der Waals Density Functional. Journal of Physics: Condensed Matter 2009, 22 (2), 022201.

12. Hamada, I., Van der Waals Density Functional Made Accurate. Physical Review B 2014, 89 (12), 121103(R).

13. Steinmann, S. N.; Corminboeuf, C., Comprehensive Benchmarking of a Density-Dependent Dispersion Correction. Journal of Chemical Theory and Computation 2011, 7 (11), 35673577.

14. Lebedeva, I. V.; Knizhnik, A. A.; Popov, A. M.; Lozovik, Y. E.; Potapkin, B. V., Interlayer Interaction and Relative Vibrations of Bilayer Graphene. Physical Chemistry Chemical Physics 2011, 13 (13), 5687-5695. 
15. Reguzzoni, M.; Fasolino, A.; Molinari, E.; Righi, M. C., Potential Energy Surface for Graphene on Graphene: Ab Initio Derivation, Analytical Description, and Microscopic Interpretation. Physical Review B 2012, 86 (24), 245434.

16. Liu, Z.; Yang, J.; Grey, F.; Liu, J. Z.; Liu, Y.; Wang, Y.; Yang, Y.; Cheng, Y.; Zheng, Q., Observation of Microscale Superlubricity in Graphite. Physical Review Letters 2012, 108 (20), 205503.

17. Leven, I.; Krepel, D.; Shemesh, O.; Hod, O., Robust Superlubricity in Graphene/h-BN Heterojunctions. The Journal of Physical Chemistry Letters 2013, 4 (1), 115-120.

18. Hod, O., The Registry Index: A Quantitative Measure of Materials' Interfacial Commensurability. ChemPhysChem 2013, 14 (11), 2376-2391.

19. Woods, C. R.; Britnell, L.; Eckmann, A.; Ma, R. S.; Lu, J. C.; Guo, H. M.; Lin, X.; Yu, G. L.; Cao, Y.; Gorbachev, R. V.; Kretinin, A. V.; Park, J.; Ponomarenko, L. A.; Katsnelson, M. I.; Gornostyrev, Y. N.; Watanabe, K.; Taniguchi, T.; Casiraghi, C.; Gao, H. J.; Geim, A. K.; Novoselov, K. S., CommensurateIncommensurate Transition in Graphene on Hexagonal Boron Nitride. Nature Physics 2014, $10(6), 451-456$.

20. van Wijk, M. M.; Schuring, A.; Katsnelson, M. I.; Fasolino, A., Moiré Patterns as a Probe of Interplanar Interactions for Graphene on $h$-BN. Physical Review Letters 2014, 113 (13), 135504. 